\title{
COMPARATIVE ANALYSIS OF CULTURAL ISOLATION AND PCR BASED ASSAY FOR DETECTION OF CAMPYLOBACTER JEJUNI IN FOOD AND FAECAL SAMPLES
}

\author{
Harkanwaldeep Singh ${ }^{1}$; R.S. Rathore ${ }^{1}$; Satparkash Singh ${ }^{2}$; Pawanjit Singh Cheema ${ }^{2 *}$ \\ ${ }^{1}$ Division of Veterinary Public Health, Indian Veterinary Research Institute, Izatnagar, Bareilly-243122, India; ${ }^{2}$ Division of \\ Bacteriology and Mycology, Indian Veterinary Research Institute, Izatnagar, Bareilly-243122, India.
}

Submitted: August 29, 2009; Approved: June 21, 2010.

\begin{abstract}
In the present study, the efficacy of polymerase chain reaction (PCR) based on mapA gene of $C$. jejuni was tested for detection of Campylobacter jejuni in naturally infected as well as spiked faecal and food samples of human and animal origin. Simultaneously, all the samples were subjected to the cultural isolation of organism and biochemical characterization. The positive samples resulted in the amplification of a DNA fragment of size $\sim 589$ bp in PCR assay whereas the absence of such amplicon in DNA extracted from $E$. coli, Listeria, Salmonella and Staphylococcus confirmed the specificity of the primers. Of randomly collected 143 faecal samples comprising human diarrheic stools (43), cattle diarrheic faeces (48) and poultry faecal swabs (52) only 4, 3 and 8, respectively, could be detected by isolation whereas 6, 3 and 10, respectively, were found positive by PCR. However, among food samples viz. beef (30), milk (35), cheese (30), only one beef sample was detected both by culture as well as PCR. Additionally, PCR was found to be more sensitive for $C$. jejuni detection in spiked faecal and food samples $(96.1 \%$ each) as relative to culture isolation which could detect the organism in $86.7 \%$ and $80 \%$ samples, respectively. The results depicted the superior efficacy of PCR for rapid screening of samples owing to its high sensitivity, specificity and automation potential.
\end{abstract}

Key words: Campylobacter jejuni, isolation, PCR, spiking

\section{INTRODUCTION}

Different species within the genus Campylobacter have emerged over the last three decades as important clinical pathogens of human and veterinary concern. The majority of acute bacterial intestinal infections in human beings in the western countries are caused by these organisms, particularly due to thermotolerant campylobacters (11). Among these, $C$. jejuni and $C$. coli are the most common pathogens responsible for the majority of human enteritis cases $(2,15)$. C. jejuni subsp. jejuni has also been reported to cause abortion and mastitis in bovines. Besides, zoonotic campylobacters have been found associated with potentially life threatening complications like Guillain-Barre syndrome, reactive arthritis, hemolytic uraemic syndrome and meningitis etc. $(7,16,17)$. The prime cause of campylobacter infections is considered to be contaminated food as the organism is a part of normal flora in various animal species such as poultry, pigs, and cattle.

\footnotetext{
*Corresponding Author. Mailing address: Assistant Disease Investigation Officer, Department of Veterinary Public Health and Epidemiology, CCS HAU, Hisar-125004, India.; E-mail: pawanjitcheema@ gmail.com
} 
In the recent past, number of enteritis cases in humans due to campylobacters has exceeded to those caused by Salmonella and Shigella, especially in developed world. However, in developing countries, the true incidence of campylobacteriosis is often underestimated because of lack of adequate laboratory infrastructure. The conventional methods of detection of campylobacters are based on cultural isolation followed by various genus and species specific biochemical tests which are cumbersome and time consuming. The hippurate hydrolysis, a routinely performed test for identification of $C$. jejuni has its own limitations as false negative as well as false positive results with this test have been reported due to emergence of some hippurate negative $C$. jejuni strains and some hippurate positive non- $C$. jejuni strains, respectively $(5,12)$. Additionally, Campylobacter spp. can survive as viable but non culturable (VBNC) forms which may not grow on selective media. Subsequently, the refrigerated storage under reduced oxygenated conditions that occur in modified atmospheric packaging or vacuum packaging of food products may allow resuscitation of injured or VBNC Campylobacter spp, hereby rendering a potential threat to human health.

Polymerase chain reaction (PCR) assays have been widely employed for identification of the pathogens owing to their sensitivity and cost effectiveness (8). A number of PCR assays have been described for the detection of campylobacters from food and faecal samples $(1,4,6,13,14)$. The present study was carried to access the prevalence of $C$. jejuni in various food and faecal samples and to compare the efficacy of cultural and biochemical tests with PCR for detection of the organism.

\section{MATERIALS AND METHODS}

\section{Sample collection}

A total of 238 faecal and food samples of human and animal origin belonging to Uttar Pradesh state of India were included in the study. Of these, faecal samples comprised human diarrhoeic stools (43), cattle diarrhoeic faeces (48) and poultry faecal swabs (52) where as the food samples included beef (30), milk (35) and cheese (30). The samples were collected over ice maintaining all the sterility measures and brought to the laboratory in enrichment medium.

\section{Cultural and biochemical examination}

For cultural isolation of the organism, modified selective media (3) was employed. Briefly, the human and cattle diarrhoeic stool samples and faecal swabs of poultry were inoculated into modified enrichment broth and incubated at $37^{\circ} \mathrm{C}$ for $48 \mathrm{hr}$ under microaerophilic conditions $\left(5 \% \mathrm{O}_{2}, 10 \%\right.$ $\begin{array}{lll}\mathrm{CO}_{2} & \text { and } 85 \% & \mathrm{~N}_{2}\end{array}$ ) using CampyPak (BD, Oxoid) gas generating packs. The grown cultures from broth were streaked onto respective agar plates, incubated as above and were regularly observed for 5-7 days for any bacterial growth. Characteristic Campylobacter colonies were tested for genus specific phenotypic and biochemical characters i.e., Gram's staining, motility, oxidase, catalase and nitrate reduction tests followed by species specific characters i.e., hippurate hydrolysis, growth in $1 \%$ glycine, $\mathrm{H}_{2} \mathrm{~S}$ production on triple sugar iron agar, growth at $25^{\circ} \mathrm{C}$ and $42^{\circ} \mathrm{C}$ and sensitivity to nalidixic acid.

\section{Preparation of samples for PCR}

Faecal samples, five gram each from cattle, poultry and human were mixed with $50 \mathrm{ml}$ of enrichment broth so as to make a homogeneous suspension. The mixture was incubated under microaerophillic conditions at $37^{\circ} \mathrm{C}$ for $3 \mathrm{~h}$ and then for $18 \mathrm{~h}$ at $42^{\circ} \mathrm{C}$. Subsequently, it was centrifuged passively to remove the debris and $1 \mathrm{ml}$ of supernatant obtained was further centrifuged at $10000 \mathrm{xg}$ for $10 \mathrm{~min}$. The resulting pellet was resuspended in $100 \mu \mathrm{l}$ of TE buffer $(10 \mathrm{mM}$ Tris-HCl, $1 \mathrm{mM}$ EDTA, $\mathrm{pH}$ 8.0), boiled for $10 \mathrm{~min}$ followed by immediate chilling on ice. After its centrifugation at 10000xg for $10 \mathrm{~min}$, a five $\mu 1$ of the supernatant was directly used as template in 25 $\mu \mathrm{l}$ PCR reaction. For preparation of template DNA from beef and cheese, five gram minced sample from either of these was diluted ten times (w/v) in enrichment broth and later on processed in same way as that of stools. As regards milk samples, $10 \mathrm{ml}$ milk was added to $90 \mathrm{ml}$ enrichment broth and incubated as above. After incubation, $1 \mathrm{ml}$ suspension was 
centrifuged at $10000 \mathrm{xg}$ for $10 \mathrm{~min}$ and the resulting pellet was resuspended in $100 \mu \mathrm{l}$ of TE buffer $(\mathrm{pH}$ 8.0). Subsequent processing was carried out in similar manner as that of faecal samples.

\section{PCR assay}

The primers based on mapA gene of $C$. jejuni (5) were got custom synthesized. The sequences of forward and reverse oligonucleotide primers were as follows:

\section{Forward 5'-CTATTTTATTTTTGAGTGCTTGTG-3'}

Reverse 5'-GCTTTATTTGCCATTTGTTTTATTA-3'

The cyclic conditions for PCR were same as those described by Denis et al. (5) which were as follows: initial denaturation at $94^{\circ} \mathrm{C}$ for $2 \mathrm{~min}$ followed by 30 cycles of denaturation at $94^{\circ} \mathrm{C}$ for $40 \mathrm{sec}$, annealing at $54^{\circ} \mathrm{C}$ for $40 \mathrm{sec}$ and extension at $72^{\circ} \mathrm{C}$ for $1 \mathrm{~min}$ and a final extension at $72^{\circ} \mathrm{C}$ for $5 \mathrm{~min}$. The reaction mixture comprised of 1x PCR buffer [50 mM Tris- $\mathrm{HCl}, 10 \mathrm{mM} \mathrm{KCl,} 5 \mathrm{mM}\left(\mathrm{NH}_{4}\right)_{2} \mathrm{SO}_{4}, \mathrm{pH} 8.3$ ], 1.0 $\mathrm{mM} \mathrm{MgCl} 2$ (MBI fermentas, USA), $0.2 \mathrm{mM}$ dNTP mix (MBI fermentas, USA), $16 \mathrm{p}$ mol of each of the primers (Integrated DNA Technologies, Inc, IA, USA), 1 U of Taq DNA polymerase enzyme (MBI fermentas, USA), $5 \mu$ l of template DNA in $25 \mu \mathrm{l}$ of reaction mixture. The PCR products were analyzed by $1.5 \%$ agarose gel (Amersham Pharmacia Biotech AB, Uppsala, Sweden) electrophoresis and photographed using a gel documentation system (Alpha Imager, Germany).

\section{Specificity and sensitivity of PCR}

To test the specificity of primers, the PCR assay was also applied on E. coli, Salmonella, Listeria and Staphylococcus organisms. PCR reaction mixture and cyclic conditions were kept same as described above.

For testing the sensitivity of PCR, freshly grown pure culture of Campylobacter was taken and the concentration of cells in liquid culture was estimated to be $10^{9}$ cells $/ \mathrm{ml}$. From this culture, 10 fold serial dilutions were made from $10^{9}$ to $10^{4}$ cells $/ \mathrm{ml}$. Each of these dilutions was further diluted 1:10 in TE buffer ( $\mathrm{pH} 8.0$ ), boiled for $10 \mathrm{~min}$ followed by chilling over ice and centrifugation at $10000 \mathrm{xg}$ for $10 \mathrm{~min}$. A $5 \mu \mathrm{l}$ of the supernatant was used as template in the PCR, resulting in a final concentration ranging from $5 \times 10^{5}$ to $5^{1}$ cells per PCR.

\section{Artificial inoculation/Spiking studies}

The experimental inoculation studies were carried out to assess the efficacy of the standardized PCR method for the detection of $C$. jejuni in spiked faecal and food samples. Faecal samples from cattle, poultry and human were inoculated with overnight grown culture of $C$. jejuni so as to make a final concentration of $10^{6}$ bacterial cells $/ \mathrm{ml}$ of stools and the resulting mixture was centrifuged passively to remove the debris. The resulting supernatant was diluted ten times in TE buffer ( $\mathrm{pH} \mathrm{8.0)}$ and boiled for 10 min followed by immediate chilling on ice. Afterwards, it was centrifuged at 10000xg for $10 \mathrm{~min}$ and a five $\mu \mathrm{l}$ of the supernatant was used as template in PCR. For spiking of milk, overnight grown culture of $C$. jejuni was added to the pasteurized whole milk in order to achieve a final concentration of $10^{6}$ bacterial cells $/ \mathrm{ml}$ of milk. One $\mathrm{ml}$ of this spiked milk was diluted ten times in TE buffer ( $\mathrm{pH} 8.0$ ) and later on processed in a way same as that of stools for preparation of template DNA. As regards beef and cheese samples, one gram of minced beef or cheese was mixed with $10 \mathrm{ml}$ of enrichment broth and $C$. jejuni cells were added to it making a final concentration of $10^{6}$ cells $/ \mathrm{ml}$ of suspension. Subsequently, the debris was removed by passive centrifugation and the supernatant was processed for the preparation of template DNA as described elsewhere. Simultaneously, the spiked samples were also streaked onto the modified selective solid media and plates were incubated at $42^{\circ} \mathrm{C}$ for 3-5 days under microaerophilic conditions for cultural isolation of $C$. jejuni.

\section{RESULTS AND DISCUSSION}

Of 143 faecal samples, 15 were found positive for $C$. jejuni by cultural and biochemical examination, out of which 4 belonged to human, 3 to cattle and 8 to poultry (Table 1). As 
regards food samples, only one (beef) was found positive whereas all the milk and cheese samples were found negative. Biochemically, the organisms were positive for oxidase, catalase, nitrate reduction tests as well as species specific tests like hippurate hydrolysis, growth in $1 \%$ glycine and were sensitive to nalidixic acid.

Table 1. Results of cultural isolation and PCR for detection of $C$. jejuni in randomly collected faecal and food samples

\begin{tabular}{ll}
\hline Type of sample & No. of positive samples \\
Culture & PCR
\end{tabular}

\section{Faecal samples}

Human diarrhoeic stools (43)

Cattle diarrhoeic faeces (48)

Poultry faecal swabs (52)

Total (143)

\section{Food samples}

Beef (30)

Milk (35)

Cheese (30)

Total (95)

$\begin{array}{cc}4 & 6 \\ 3 & 3 \\ 8 & 10 \\ \mathbf{1 5}(\mathbf{1 0 . 5 \%}) & \mathbf{1 9}(\mathbf{1 3 . 3 \%})\end{array}$

$\begin{array}{cc}1 & 1 \\ 0 & 0 \\ 0 & 0 \\ \mathbf{1}(\mathbf{1 . 0 5 \% )} & \mathbf{1 ( 1 . 0 5 \% )}\end{array}$

PCR detected all those faecal samples found positive by cultural examination as a fragment of size $\sim 589$ bp (Fig. 1) was amplified from these samples. Additionally, four more samples were found positive which were culturally negative; 2 each from human diarrhoeic stools and poultry faecal swabs, respectively. Hence, PCR was found more efficient for detecting $C$. jejuni from faecal samples $(10.5 \%$ by culture versus $13.3 \%$ by PCR). Earlier workers have also demonstrated the superior efficacy of PCR in detection of the campylobacters from faecal samples declared negative by selective cultural and biochemical tests $(9,10)$.

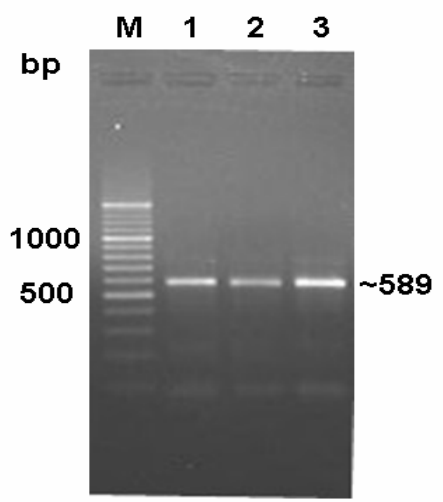

Fig 1
Figure 1. PCR amplification of mapA gene from representative samples for detection of Campylobacter jejuni. Lane M: DNA ladder. Lanes 1 to 3: human diarrhoeic stool, cattle diarrhoeic faeces and poultry faecal swab samples, respectively.
Regarding food samples, no difference was observed in PCR and culture isolation methods for detection of organism as only one beef sample was detected by PCR that was found positive by selective culture method also. Low incidence of $C$. jejuni in raw beef (3.2\%) and raw bulk tank milk samples $(1.6 \%)$ has been reported earlier also (19).

As isolation and identification of the campylobacters based on selective culture and biochemical differentiation upto species level is tedious, time consuming and has been proved time and again not very reliable. Hence, on the basis of our study, we can say that PCR based methods are more rapid and reliable, particularly while processing a large number of samples.

No amplification was observed in PCR using DNA extracted from E. coli, Listeria, Salmonella and Staphylococcus organisms (Fig. 2). The absence of desired amplicon from these organisms confirmed the specificity of the primers. Regarding sensitivity of PCR on DNA extracted from pure culture of $C$. jejuni by heat lysis method, upto a minimum of 50 cells per PCR reaction (corresponding to $10^{5}$ cells $/ \mathrm{ml}$ of culture) were detected. However, the intensity of amplicons gradually improved with increase in concentration of cells (Fig. 
3). High sensitivity of PCR assay for detection of $C$. jejuni from pure culture was in agreement with observation of Perssson and Olsen (13) who detected 10-100 cells per PCR reaction.

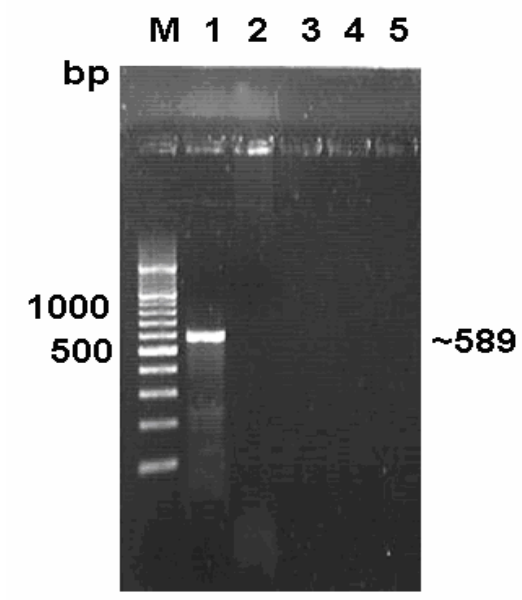

Figure 2. Specificity study of PCR amplification of mapA gene. Lane M: DNA ladder. Lane 1: Campylobacter jejuni. Lane 2: E. coli. Lane 3: Salmonella. Lane 4: Listeria. Lane 5: Staphylococcus.

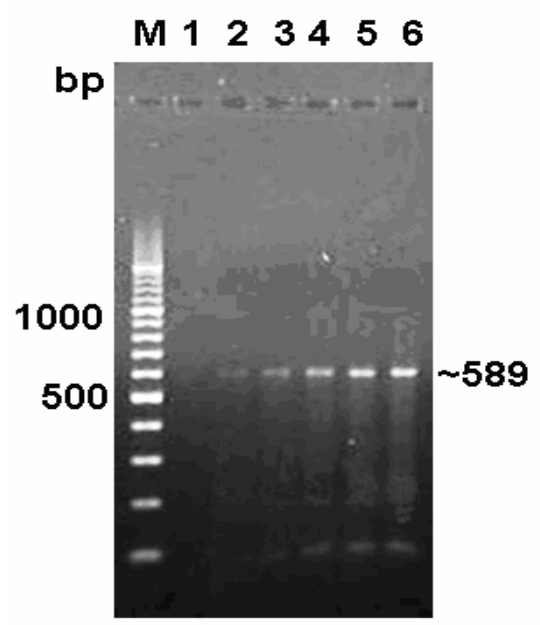

Figure 3. Sensitivity assay of PCR by 10 fold dilution of bacterial DNA derived from Campylobacter jejuni culture. Lane M: DNA ladder. Lanes 1 to $6: 10^{4}, 10^{5}, 10^{6}, 10^{7}, 10^{8}, 10^{9}$ cells/ml respectively.

As regards artificial inoculation studies, culture and biochemical identification could detect $26(86.7 \%)$ of 30 faecal samples and 24 (80\%) of 30 food samples whereas $29(96.1 \%)$ each of faecal and food samples were found positive in PCR assay (Table 2). Persson and Olsen (13) and Waage et al. (18) have also found PCR to be quite effective in detection of $C$. jejuni from spiked samples. Our study on spiked samples further underscores the better efficacy of PCR over cultural identification of the organism and bolsters the application of technique in randomly collected faecal and food samples.

Table 2. Comparison of culture and PCR for detection of $C$. jejuni in spiked faecal and food samples

\begin{tabular}{lcc}
\hline Type of Sample & \multicolumn{2}{c}{ No. of positive samples } \\
Culture & PCR \\
\hline a) Faecal samples & & \\
Cattle diarrhoeal faeces (10) & 9 & 10 \\
Human diarrhoeal stools (10) & 8 & 9 \\
Poultry faecal swabs (10) & 9 & 10 \\
Total (30) & $\mathbf{2 6}(\mathbf{8 6 . 7 \% )}$ & $\mathbf{2 9}(\mathbf{9 6 . 1 \%})$ \\
b) Food samples & & \\
Beef (10) & 9 & 10 \\
Cheese (10) & 7 & 9 \\
Milk (10) & 8 & 10 \\
Total (30) & $\mathbf{2 4}(\mathbf{8 0 \%})$ & $\mathbf{2 9}(\mathbf{9 6 . 1 \%})$ \\
\hline
\end{tabular}

\section{REFERENCES}

1. Al Amri, A.; Senok, A.C.; Ismaeel, A.Y.; Al-Mahmeed, Ali E.; Botta, Giuseppe A. (2007). Multiplex PCR for direct identification of Campylobacter spp. in human and chicken stools. J. Med. Microbiol. 56, 1350-1355.

2. Allos, B.M.; Blaser, M.J. (1995). C. jejuni and expanding spectrum of related infections. Clin. Infect. Dis. 20, 1092-1099.

3. Barua, R.; Rathore, R.S. (2006). Development of modified selective media for the isolation of Campylobacter jejuni from poultry. J. Food Sci. Technol. 43, 305-307.

4. Debruyne, L.; Samyn, E.; De Brandt, E.; Vandenberg, O.; Heyndrickx, M.; Vandamme, P. (2008). Comparative performance of different PCR assays for the identification of Campylobacter jejuni and Campylobacter coli. Res. Microbiol. 159, 88-93.

5. Denis, M.; Soumet, C.; Rival, K.; Ermel, G.; Salavat, G.; Colin, P. (1999). Development of a mPCR assay for simultaneous identification of Campylobacter jejuni and C. coli. Lett. Appl. Microbiol. 29, 406-410.

6. Jackson, C.J.; Fox, A.J.; Jones, D.M. (1996). A novel polymerase chain reaction assay for the detection and speciation of thermophilic Campylobacter spp. J. Appl. Bacteriol. 81, 467-473.

7. Kopyta, I.; Wardak, S. (2008). Campylobacter jejuni infection in patient with Guillain Barre syndrome- Clinical case report. Med. Dosw. Mikrobiol. 60, 59-63. 
8. Kricka, L.J. (1998). Prospects for chemiluminescent and bioluminescent immunoassay and nucleic acid assays in food testing and the pharmaceutical industry. J. Biolumin. Chemilumin. 13, 189-193.

9. Kulkarni, S.P.; Lever, S.; Logan, J.M.; Lawson, A.J.; Stanley, J.; Shafi, M. (2002). Detection of Campylobacter species: a comparison of culture and polymerase chain reaction based methods. J. Clin. Pathol. 55, 749753.

10. Lawson, A.J.; Shafi, M.S.; Pathak, K.; Stanley, J. (1998). Detection of Campylobacter in gastroenteritis: Comparison of direct PCR assay of faecal samples with selective culture. Epidemiol. Infect. 121, 547-553.

11. Maher, M.; Finnegan, C.; Collins, E.; Ward, B.; Carroll, C.; Cormican, M. (2003). Evaluation of culture methods and a DNA probe-based PCR assay for detection of Compylobacter spp. in clinical specimens of faeces. J. Clin. Microbiol. 41, 2980-2986.

12. Morris, G.K.; El Sherbeeny, M.R.; Patton, C.M.; Kodaka, H.; Lombard, G.L.; Edmonds, P.; Hollis, D.G.; Brenner, D.J. (1985). Comparison of four hippurate hydrolysis methods for identification of thermophilic Campylobacter spp. J. Clin. Microbiol. 22, 714-718.

13. Persson, Søren; Olsen, Katharina E.P. (2005). Multiplex PCR for identification of Campylobacter coli and Campylobacter jejuni from pure cultures and directly on stool samples. J. Med. Microbiol. 54, 1043-1047.

14. Sails, Andrew D.; Fox, A.J.; Bolton, F.J.; Wareing, D.R.A.; Greenway, D.L.A. (2003). A Real-Time PCR Assay for the detection of Campylobacter jejuni in foods after enrichment culture. Appl. Environ. Microbiol. 69, 1383-1390.

15. Skirrow, M.B. (1994). Disease due to Campylobacter, Helicobacter and related bacteria. J. Comp. Pathol., 111, 113-149.

16. Stanfford, T.D.; Tenkate, R.J. (2001). Risk factors for Campylobacter infection in infants and young children: A matched case control study. Epidemiol. Infect. 127, 399-404.

17. Stern, N.D.; Line, J.E. (2000). Campylobacter. In: The microbiological safety and quality of food, pp. 1040-1056.

18. Waage, A.S.; Vardund, T.; Lund, V.; Kapperud, G. (1999). Detection of small numbers of Campylobacter jejuni and Campylobacter coli cells in environmental water, sewage, and food samples by a seminested PCR assay. Appl. Environ. Microbiol. 65, 1636-1643.

19. Whyte, P.; McGill, K.; Cowley, D.; Madden, R.H.; Moran, L.; Scates, P.; Cauoll, C.; O’Leary, A.; Funning, S.; Collins, J.D.; McNamara, E.; Moore, J.E.; Cormican, M. (2004). Occurrence of Campylobacter in retail food in Ireland. Int. J. Food Microbiol. 95, 111-118. 